DE

M E D I C I N A

T R O P I C A L

$\mathrm{DE}$

SÃO PAULO

JOURNAL OF THE SÃO PAULO INSTITUTE OF TROPICAL MEDICINE

'Universidade de São Paulo, Faculdade de Saúde Pública, São Paulo, São Paulo, Brazil

2Universidade de São Paulo, Instituto de Medicina Tropical de São Paulo, São Paulo, São Paulo, Brazil

${ }^{3}$ Divisão de Vigilância de Zoonoses, Laboratórios de Identificação e Pesquisa em Fauna Sinantrópica, São Paulo, São Paulo Brazil

${ }^{4}$ Universidade Estadual de Campinas, Departamento de Biologia Animal, Campinas, São Paulo, Brazil

${ }^{5}$ Secretaria de Estado da Saúde, Superintendência de Controle de Endemias, Divisão de Programas Especiais, São Paulo, São Paulo Brazil

'Secretaria de Estado da Saúde, Superintendência de Controle de Endemias, Departamento de Combate a Vetores, São Paulo, São Paulo Brazil

${ }^{7}$ Universidade Estadual Paulista Júlio de Mesquita Filho, Departamento de Ciências Biológicas, Araraquara, São Paulo, Brazil

Correspondence to: Mauro Toledo Marrelli Universidade de São Paulo, Faculdade de Saúde Pública, Departamento de Epidemiologia, Av. Dr. Arnaldo, 715, CEP 01246-904, São Paulo, SP, Brazil

Tel: +55 1130617922

E-mail: mmarelli@usp.br

Received: 1 March 2018

Accepted: 24 May 2018

\section{Occurrences of triatomines (Hemiptera: Reduviidae) and first reports of Panstrongylus geniculatus in urban environments in the city of Sao Paulo, Brazil}

\author{
Walter Ceretti-Junior ${ }^{1}$, Daniel Pagotto Vendrami ${ }^{2}$, Marco Otavio de Matos- \\ Junior $^{3}$, Aline Rimoldi-Ribeiro ${ }^{4}$, Julia Vono Alvarez ${ }^{3}$, Sandro Marques ${ }^{3}$, \\ Agnaldo Nepomuceno Duarte ${ }^{5}$, Rubens Antonio da Silva ${ }^{6}$, João Aristeu da \\ Rosa7, Mauro Toledo Marrelli',2
}

\section{ABSTRACT}

This note reports on occurrences of triatomine species in the city of Sao Paulo, Brazil, registered between 1988 and 2017. Records of triatomines captured in Sao Paulo are based on specimens received spontaneously from Health Surveillance Centers, Health Centers and Zoonosis Control Centers in the city as well as from citizens. Species were identified morphologically at the Public Health Entomology Laboratory, Faculty of Public Health, University of Sao Paulo, where the triatomines, which are vectors of Chagas disease, were tested for Trypanosoma cruzi infection. The first reported occurrence of triatomine bugs in urban Sao Paulo was in 1988. The specimen, which was captured in Jardim Sao Luiz district, was from the genus Panstrongylus and was registered as Panstrongylus sp. but was not sexed. Since this first recorded occurrence, the following species have been found in the city: Panstrongylus geniculatus (2 occurrences), P. megistus (15 occurrences), Triatoma infestans ( 1 occurrence) and T. sordida (3 occurrences). In this paper, the importance of reporting occurrences of triatomine bugs in the city of Sao Paulo, one of the largest metropolis in the world, is discussed with an emphasis on P. megistus. The occurrences discussed here indicate the importance of entomological surveillance for these vectors even in urban centers although the possibility of vector transmission of Chagas disease in these centers is very low.

KEYWORDS: Hemiptera. Reduviidae. Triatominae species. Entomological surveillance. Urban center, Trypanosoma cruzi, Chagas disease.

\section{INTRODUCTION}

Chagas disease is caused by the protozoan Trypanozoma cruzi and is an endemic disease in 21 Latin American countries ${ }^{1}$. It is one of 17 diseases classified as neglected tropical diseases by the World Health Organization, and it is estimated that there are around 8 million people worldwide infected by this parasite ${ }^{1}$, with Brazil accounting for more than 1.1 million of them ${ }^{2}$. Trypanosoma cruzi is naturally transmitted to humans and other mammals through feces and urine eliminated by infected triatomine bugs. Transmission occurs during or shortly after the vector sucks blood from the host, when its feces or urine penetrate the host's skin or mucous membranes ${ }^{3}$. Other forms of transmission include the oral transmission following ingestion of food contaminated with $T$. cruzi, blood transfusion, organ transplantation from donors with Chagas disease, congenital transmission, breastfeeding and accidental transmission ${ }^{4}$. 
Triatomines are currently distributed in five tribes and 18 genera, totaling 153 recognized species ${ }^{5}$. Of these genera, Panstrongylus, Rhodnius and Triatoma have the most described epidemiologically important species ${ }^{6}$. This note reports on occurrences of triatomine bugs in the municipality of Sao Paulo, SP, Brazil, registered between 1988 and 2017 by the Synanthropic Fauna Identification and Research Laboratory (Labfauna), Zoonosis Surveillance Division, City of Sao Paulo, and the Public Health Entomology Laboratory (LESP), Faculty of Public Health, University of Sao Paulo.

\section{MATERIALS AND METHODS}

The records of triatomines captured in the city of Sao Paulo discussed in this note are based on specimens sent spontaneously to Labfauna and LESP by Health Surveillance Centers, Health Centers and Zoonosis Control Centers in the city as well as by citizens.

Morphological species identification and confirmation and, when possible, testing of specimens for T. cruzi infection is normally performed by LESP that keeps records of occurrences of triatomines dating from 1983. The records refer to triatomine bugs in Brazil as well as in other countries.

Labfauna has provided taxonomic identification of synanthropic animals since 1982. The service, which is free, consists of the receiving, taxonomic identification and preservation or disposal of specimens and preparation of technical reports. Specimens received at the laboratory act as sentinels for the presence of species associated with human health risks. Here we discuss only occurrences of triatomines in the municipality of Sao Paulo.

\section{RESULTS}

The results are shown in Table 1 in alphabetical order by species and consist of sex, parasitological tests results, district where the specimen came from, corresponding coordinates and year of registration.

Although it was initiated in the years 1982 (Labfauna) and 1983 (LESP), the first occurrence of triatomines

Table 1 - Occurrences of Triatominae species in the city of Sao Paulo from 1988 to 2017 recorded by Labfauna and LESP, in chronological order. The following data are shown for each occurrence: sex, result of parasitological examination, district where the specimen was captured, coordinates and year of registration. (N: number of specimens; NS: not sexed; NI: no information)

\begin{tabular}{|c|c|c|c|c|c|}
\hline Taxon & $N / \operatorname{Sex}$ & Infect. T. cruzi & District & Coordinates & Year \\
\hline P. geniculatus & $1 / N S$ & $\mathrm{NI}$ & Cursino & $23^{\circ} 36^{\prime} 10^{\prime \prime}$ S $46^{\circ} 37^{\prime} 32^{\prime \prime} \mathrm{W}$ & 1999 \\
\hline P. geniculatus & $1 / \widehat{3}$ & $\mathrm{NI}$ & Morumbi & $23^{\circ} 35^{\prime} 46^{\prime \prime}$ S $46^{\circ} 41^{\prime} 42^{\prime \prime} \mathrm{W}$ & 2014 \\
\hline P. megistus & $1 / N S$ & $\mathrm{NI}$ & Sacoma & $23^{\circ} 38^{\prime} 57^{\prime \prime}$ S $46^{\circ} 36^{\prime} 49^{\prime \prime} \mathrm{W}$ & 1996 \\
\hline P. megistus & $1 / \hat{O}$ & $\mathrm{NI}$ & Jabaquara & $23^{\circ} 37^{\prime} 33^{\prime \prime}$ S 46³8'26” W & 1999 \\
\hline P. megistus & $1 / \hat{O}$ & $\mathrm{NI}$ & Jabaquara & $23^{\circ} 39^{\prime} 33^{\prime \prime}$ S 46³8'48” W & 1999 \\
\hline P. megistus & $1 / \mathrm{NS}$ & $\mathrm{NI}$ & Cursino & $23^{\circ} 38^{\prime} 30^{\prime \prime} \mathrm{S} 46^{\circ} 36^{\prime} 45^{\prime \prime} \mathrm{W}$ & 2003 \\
\hline P. megistus & $1 / \hat{0}$ & $\mathrm{NI}$ & Cursino & $23^{\circ} 37^{\prime} 43^{\prime \prime}$ S $46^{\circ} 37^{\prime} 12^{\prime \prime} \mathrm{W}$ & 2003 \\
\hline P. megistus & $1 / \mathrm{NS}$ & $\mathrm{NI}$ & Jaragua & $23^{\circ} 27^{\prime} 21^{\prime \prime} \mathrm{S} 46^{\circ} 45^{\prime \prime} 46^{\prime \prime} \mathrm{W}$ & 2004 \\
\hline P. megistus & $1 / \mathrm{NS}$ & $\mathrm{NI}$ & Jardim Angela & $23^{\circ} 41^{\prime} 41^{\prime \prime} \mathrm{S} 46^{\circ} 45^{\prime} 30^{\prime \prime} \mathrm{W}$ & 2005 \\
\hline P. megistus & $1 / \mathrm{NS}$ & $\mathrm{NI}$ & Cursino & $23^{\circ} 37^{\prime} 50^{\prime \prime}$ S $46^{\circ} 36^{\prime} 47^{\prime \prime} \mathrm{W}$ & 2007 \\
\hline P. megistus & $1 / \hat{0}^{\lambda}$ & $\mathrm{NI}$ & Jaragua & $23^{\circ} 27^{\prime} 50^{\prime \prime} \mathrm{S} 46^{\circ} 45^{\prime} 15^{\prime \prime} \mathrm{W}$ & 2007 \\
\hline P. megistus & $1 /$ + & $\mathrm{NI}$ & Jabaquara & $23^{\circ} 38^{\prime} 7^{\prime \prime} \mathrm{S} 46^{\circ} 38^{\prime} 39^{\prime \prime} \mathrm{W}$ & 2007 \\
\hline P. megistus & $1 / 0^{\lambda}$ & Positive & Jabaquara & $23^{\circ} 39^{\prime} 18^{\prime \prime} \mathrm{S} 46^{\circ} 38^{\prime} 39^{\prime \prime} \mathrm{W}$ & 2011 \\
\hline P. megistus & $1 / \hat{3}$ & $\mathrm{NI}$ & Pedreira & $23^{\circ} 41^{\prime} 51^{\prime \prime} \mathrm{S} 46^{\circ} 37^{\prime} 46^{\prime \prime} \mathrm{W}$ & 2012 \\
\hline P. megistus & $1 /$ + & Negative & Sacoma & $23^{\circ} 38^{\prime} 30^{\prime \prime}$ S $46^{\circ} 36^{\prime} 45^{\prime \prime} \mathrm{W}$ & 2014 \\
\hline P. megistus & $1 / q$ & $\mathrm{NI}$ & Raposo Tavares & $23^{\circ} 36^{\prime} 10^{\prime \prime} \mathrm{S} 46^{\circ} 47^{\prime} 43^{\prime \prime} \mathrm{W}$ & 2015 \\
\hline P. megistus & $1 /$ q & $\mathrm{NI}$ & Raposo Tavares & $23^{\circ} 36^{\prime} 19.31^{\prime \prime S} 46^{\circ} 47^{\prime} 22^{\prime \prime} \mathrm{W}$ & 2017 \\
\hline Panstrongylus sp. & $1 / \mathrm{NS}$ & $\mathrm{NI}$ & Jardim São Luiz & $23^{\circ} 42^{\prime} 23.17^{\prime \prime} \mathrm{S} 46^{\circ} 44^{\prime} 21$. . W $^{\prime}$ & 1988 \\
\hline T. infestans & $1 / \widehat{O}$ & $\mathrm{NI}$ & Vila Mariana & $23^{\circ} 35^{\prime} 51^{\prime \prime} \mathrm{S} 46^{\circ} 39^{\prime} 65^{\prime \prime} \mathrm{W}$ & 2004 \\
\hline T. sordida & 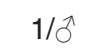 & $\mathrm{NI}$ & Jose Bonifacio & $23^{\circ} 32^{\prime} 43.98^{\prime \prime S} 46^{\circ} 26^{\prime} 17^{\prime \prime} \mathrm{W}$ & 2008 \\
\hline T. sordida & $1 / q$ & $\mathrm{NI}$ & Vila Curuça & $23^{\circ} 31^{\prime} 42^{\prime \prime}$ S $46^{\circ} 23^{\prime} 49^{\prime \prime} \mathrm{W}$ & 2013 \\
\hline T. sordida & $1 /$ + & $\mathrm{NI}$ & Vila Prudente & $23^{\circ} 35^{\prime} 40^{\prime \prime}$ S $46^{\circ} 34^{\prime} 53^{\prime \prime} \mathrm{W}$ & 2017 \\
\hline
\end{tabular}


reported by these laboratories in the city of Sao Paulo was in 1988. The specimen, which was captured in the Jardim Sao Luiz district, was from the genus Panstrongylus and was registered as Panstrongylus sp. but was not sexed. Since this first occurrence, the following species of triatomine bugs have been found in Sao Paulo: P. geniculatus (2 occurrences), P. megistus (15 occurrences), T. infestans (1 occurrence) and T. sordida (3 occurrences). None of the reports indicated domiciliation of the insect. Most of the vectors occurrences in the municipality of Sao Paulo are related to areas in the South of the city that are near remnants of the Atlantic Rainforest (Figure 1). Among the triatomines submitted to parasitological examination, one P. megistus specimen, a male captured in the district of Jabaquara, was positive for T. cruzi, according to Ribeiro et al. ${ }^{7}$.
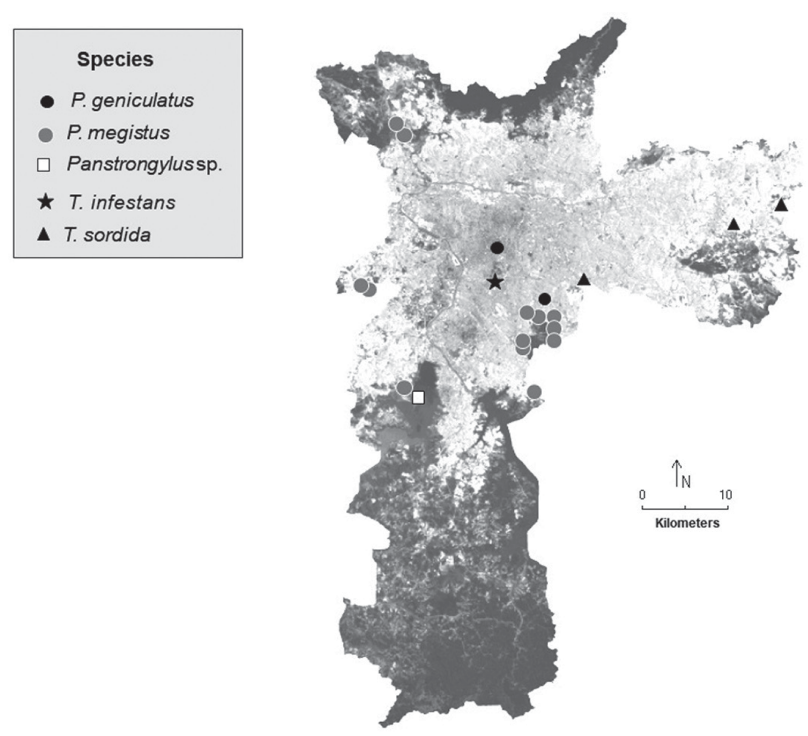

Figure 1 - Occurrences of triatomines in the city of Sao Paulo from 1982 to 2017 recorded by Labfauna and LESP

\section{DISCUSSION}

The city of Sao Paulo, one of the largest metropolis in the world with an estimated population of 12 million, the largest in the Southern hemisphere, suffers from severe environmental stress. Because of an extensive human interference in the natural environment, the remaining forest fragments are now found only in parks, gardens and environmental protection areas ${ }^{8,9}$.

The city of Sao Paulo is located in what was formerly the Atlantic rainforest, an environment with high biodiversity considered one of the 23 "biodiversity hotspots" worldwide ${ }^{10}$. Despite the intense expansion of the city in the last five decades, there have been sporadic occurrences of triatomine bugs on the outskirts of Sao Paulo, some in unusual situations ${ }^{7,11}$
The only occurrence of $T$. infestans reported in the city of Sao Paulo was in 2004 in the men's restroom at the Dante Pazzanese Hospital, a national reference center for treatment of Chagas disease. The specimen may have escaped from the triatomine colonies maintained by the hospital for xenodiagnosis. In 2006, Brazil received the international certification for interruption of transmission of Chagas disease by this species from the Pan American Health Organization ${ }^{12,13}$.

In the State of Sao Paulo, a campaign against the vector of Chagas disease began in $1951^{14,15}$. Although T. infestans was eliminated from the State by 1990 as a result of the campaign, control activities were not interrupted because of the possibility of sporadic passive reintroduction of T. infestans in isolated locations, as reported by Leite et al. ${ }^{14}$ following the finding of 109 specimens of this species in the municipality of Paulinia, in the State of Sao Paulo, between 1999 and 2000. This was the last reported occurrence of the species in the State.

One reason for continued triatomine surveillance and control activities in the city of Sao Paulo was the presence of species considered important in the transmission of $T$. cruzi, such as T. sordida and P. megistus, in large areas of Brazil, including the State of Sao Paulo. These species are found colonizing households mainly in annexes and outhouses. Another reason for continued surveillance was the report of invasions of households by Rhodnius neglectus in the area of the State corresponding to the Eastern Plateau, Peripheral Depression and Western Plateau and by Triatoma tibiamaculata on the State coastline ${ }^{15}$.

In the case of $T$. sordida, it is most likely that specimens were taken to the capture locations by passive dispersion as the residents in these locations reported that they had returned from trips to endemic regions. Another possibility is the dispersion by animals, particularly birds, as T. sordida feeds preferentially on birds ${ }^{16}$. Nymphs and eggs of the species can be dispersed over large areas extending far from the original source of infestation/colonization. The species has a widespread distribution and is found in Argentina, Bolivia, Uruguay and Paraguay and the States of Bahia, Goias, Mato Grosso, Mato Grosso do Sul, Minas Gerais, Parana, Pernambuco, Piaui, Rio Grande do Sul, Santa Catarina and Sao Paulo in Brazil ${ }^{17,18}$. In Sao Paulo and other States, it is found mainly in cerrado (savannahlike grasslands) biomes. It is the most captured vector of Chagas disease, and there have been numerous reports of the species in chicken coops in peridomestic areas with a low $T$. cruzi infection rate ${ }^{16,19,20}$.

Triatoma sordida populations infected by T. cruzi persist even after insecticide has been sprayed because they are autochthonous to the territories where they occur and, after 
sheltering in the peridomestic area, can reinfest dwellings once the residual effect of the insecticide has worn off ${ }^{16,21}$.

Most captures of P. megistus in the city of Sao Paulo have been in neighborhoods on the Southern outskirts of the city in areas close to Sao Paulo Zoo, Safari Zoo, the Botanic Gardens and the USP Science and Technology Park, all of which receive large numbers of visitors (Table 1). This suggests that populations of this species remain in forest fragments, where they can perpetuate the T. cruzi sylvatic transmission cycle within the boundaries of the municipality of Sao Paulo. In 2016, Ribeiro et al. ${ }^{7}$ reported positivity for T. cruzi in a P. megistus bug captured in an urban area of the city. In a study of epidemiological surveillance in Sao Paulo between 2010 and 2012, Silva et al. ${ }^{20}$ found that this species was the most important vector of Chagas disease in the State, a finding reflected in its increasing domiciliation and high natural-infection index (23.6\%).

Panstrongylus geniculatus (Latreille 1811), which has been found naturally infected with $T$. cruzi, has a distribution extending from Southern Mexico to Northern Argentina. Although its habitats include a wide range of biomes and climates ${ }^{17,22}$, its most common habitat is wild forest environments, where it is found in armadillo (Dasypodidae) burrows and opossum (Didelphis) dens ${ }^{23,24}$. Although associated with wild environments, there are reports of the species attacking people ${ }^{24}$. It has been captured in pigsties and in environments occupied by humans, where it is attracted to light, although without forming colonies in the domicile ${ }^{23-26}$. Despite the limited vector potential of $P$. geniculatus, this triatomine can be epidemiologically important and has been involved in domestic cycles of T. cruzi in Venezuela ${ }^{27,28}$, Colombia $^{29}$, Brazil $^{23,30-32}$, Peru $^{33,34}$, Bolivia $^{35,36}$ and Argentina ${ }^{37}$, in the former in an outbreak of Chagas disease due to oral transmission at a school on the outskirts of Caracas ${ }^{38,39}$ and Colombia ${ }^{40}$.

Two occurrences of P. geniculatus in the city of Sao Paulo have been reported. The first was of an adult bug found in a neighborhood in the Southern area of the city in 1999, and the second was in July 2014 when a specimen was captured in a Culex quinquefasciatus mosquitobreeding facility next to the Pinheiros River (Figure 1). After the specimen had been identified, analysis to detect T. cruzi infectivity was conducted according to Ribeiro et $a l^{7}$, with negative result. Fifteen days after the specimen was captured, an active search was conducted within a radius of about $250 \mathrm{~m}$ of the capture site to locate possible shelters of this triatomine, and five Noireau traps ${ }^{41}$ adapted according to Obara et al..$^{42}$ were installed. However, none of the procedures resulted in any further captures.

Although the active search for triatomines was negative, the presence of colonies in the area surrounding the breeding facility cannot be completely ruled out as there are remnants of reforestation and landscaping that provide shelter for rodents and other food sources for triatomines, such as opossums and birds. This species has a wide distribution and could be authoctonous in the area ${ }^{17,22}$.

Chagas disease is associated with poverty and inadequate sanitation in the dwellings of at-risk populations ${ }^{2}$, and transmission of the disease to humans typically occurs in wild, rural and periurban areas. However, with fragmentation of the natural habitats of the vectors of the disease as a result of urbanization and the increasing use of land for crops and pastures, triatomines, which were previously found exclusively in wild environments, are now commonly found in households, particularly on the outskirts of cities ${ }^{39,42,43-45}$.

Data on occurrences of triatomines in the city of Sao Paulo indicate the importance of entomological surveillance of these vectors even in urban centers. Although the possibility of vector transmission of Chagas disease in major urban centers is very small, it cannot be ignored. If infected, triatomines that have invaded households and other buildings, to which they are attracted to by various factors, including light, can transmit the etiological agent of Chagas disease to humans and animals. As triatomines can contaminate food and other household items with their urine and feces, it is also important to consider the risk of oral transmission, the main form of transmission of T. cruzi today. Examples of this type of transmission have been reported in urban centers in recent decades and include a case involving T. sordida in the State of Bahia, Brazil, and another involving $P$. geniculatus in Caracas, Venezuela, in which contaminated water and guava juice, respectively, were ingested ${ }^{39,46}$. Accidents as a result of handling of the insect by humans or ingestion by domestic animals can also occur in large urban centers, where people are often not familiar with the appearance of these vectors.

These facts imply that in order to prevent the eventual transmission of T. cruzi in the municipality of Sao Paulo, the community is encouraged to send any suspicious insects to the local Health Supervisors (SUVIS) and that the communication between the laboratories that participated in this article, together with the Department of Health Coordination Sanitary Surveillance (COVISA) and Superintendence of Control of Endemic Diseases (SUCEN) are further narrowed, allowing a faster flow of specimens for identification and parasitological examinations, as well as more effective sharing of information.

\section{CONFLICT OF INTERESTS}

No competing financial conflicts of interest exist. 


\section{ACKNOWLEDGMENTS}

The authors would like to thank the Special Programs Division in the Superintendency for the Control of Endemic Disease (SUCEN) and the Synanthropic Fauna Identification and Research Laboratory in the Zoonoses Surveillance Division, City of Sao Paulo, for providing technical support to the field work. DPV is the recipient of a PhD fellowship from FAPESP (2012/19238-4).

\section{REFERENCES}

1. World Health Organization. Chagas disease in Latin America: an epidemiological update based on 2010 estimates. Wkly Epidemiol Rec. 2015;90:33-44.

2. Dias JC, Ramos Jr AN, Gontijo ED, Luquetti A, Shikanai-Yasuda MA, Coura JR, et al. II consenso brasileiro em doença de Chagas, 2015. Epidemiol Serv Saude. 2016;25 n. esp:7-86.

3. Moncayo A. Progress towards interruption of transmission of Chagas disease. Mem Inst Oswaldo Cruz. 1999;94 Suppl 1: 401-4.

4. Dias JC, Amato-Neto V, Luna EJ. Mecanismos alternativos de transmissão do Trypanosoma cruzi no Brasil e sugestões para sua prevenção. Rev Soc Bras Med Trop. 2011;44:375-9.

5. Oliveira JD, Alevi KC. Taxonomic status of Panstrongylus herreri Wygodzinsky, 1948 and the number of Chagas disease vectors. Rev Soc Bras Med Trop. 2017;50:434-5.

6. Schofield CJ. Triatominae: biología y control. West Sussex: Eurocommunica; 1994

7. Ribeiro AR, Oliveira RC, Ceretti Junior W, Lima L, Almeida LA, Nascimento JD, et al. Trypanosoma cruzi isolated from a triatomine found in one of the biggest metropolitan areas of Latin America. Rev Soc Bras Med Trop. 2016;49:183-9.

8. Medeiros-Sousa AR, Ceretti Junior W, Urbinatti PR, Carvalho GC, Paula MB, Fernandes A, et al. Mosquito fauna in municipal parks of Sao Paulo City, Brazil: a preliminary survey. J Am Mosq Control Assoc. 2013;29:275-9.

9. Instituto Brasileiro de Geografia e Estatística. Estimativas de população. [cited 2018 May 24]. Available from: https://www. ibge.gov.br/estatisticas-novoportal/sociais/populacao/9103estimativas-de-populacao.html?=\&t=o-que-e

10. Myers N, Mittermeier RA, Mittermeier CG, Fonseca GA, Kent J. Biodiversity hotspots for conservation priorities. Nature. 2000;403:853-8.

11. Forattini OP, Rabello EX, Castanho ML, Pattoli DG. Aspectos ecológicos da tripanossomose americana. I - Observações sôbre o Panstrongylus megistus e suas relações com focos naturais da infecção, em área urbana da cidade de São Paulo, Brasil. Rev Saude Pub. 1970;4:19-30.

12. Dias JC. Southern Cone Initiative for the elimination of domestic populations of Triatoma infestans and the interruption of transfusional Chagas disease. Historical aspects, present situation and perspectives. Mem Inst Oswaldo Cruz. 2007; 102 Suppl 1:11-8.

13. Abad-Franch F, Diotaiuti L, Gurgel-Gonçalves R, Gürtler RE. Certifying the interruption of Chagas disease transmission by native vectors: cui bono? Mem Inst Oswaldo Cruz. 2013;108:251-4.

14. Leite OF, Alves MJ, Souza SS, Mayo RC, Andrade VR, Souza CE, et al. Triatoma infestans em área sob vigilância entomológica para doença de Chagas, Estado de São Paulo, Brasil. Rev Soc Bras Med Trop. 2001;34:437-43.

15. Wanderley DM, Silva RA, Carvalho ME, Barbosa GL. Doença de Chagas: a vigilância entomológica no Estado de São Paulo. Bol Epidemiol Paulista. 2007;4:8-12.

16. Rossi JC, Duarte EC, Gurgel-Gonçalves R. Factors associated with the occurrence of Triatoma sordida (Hemiptera: Reduviidae) in rural localities of Central-West Brazil. Mem Inst Oswaldo Cruz. 2015;110:192-200.

17. Lent H, Wygodzinsky P. Revision of the triatominae (Hemiptera: Reduviidae), and their significance as vectors of Chagas' disease. Bull Am Mus Nat Hist. 1979;163:123-520

18. Gurgel-Gonçalves R, Ferreira JB, Rosa AF, Bar ME, Galvão C. Geometric morphometrics and ecological niche modelling for delimitation of near-sibling triatomine species. Med Vet Entomol. 2011;25:84-93.

19. Oscherov EB, Bar ME, Damborsky MP, Milano AM, Avalos G, Borda MA. Epidemiología de la enfermedad de Chagas, Departamento General Paz, Argentina. Rev Saude Publ. 2003;37:59-64.

20. Silva RA, Barbosa GL, Rodrigues VL. Vigilância epidemiológica da doença de Chagas no estado de São Paulo no período de 2010 a 2012. Epidemiol Serv Saude. 2014;23:259-67.

21. Macchiaverna NP, Gaspe MS, Enriquez GF, Tomassone L, Gürtler RE, Cardinal MV. Trypanosoma cruzi infection in Triatoma sordida before and after community-wide residual insecticide spraying in the Argentinean Chaco. Acta Trop. 2015;143:97102.

22. Leite GR, Santos CB, Falqueto A. Insecta, Hemiptera, Reduviidae, Panstrongylus geniculatus: geographic distribution map. Check List. 2007;3:147-52.

23. Valente VC, Valente SA, Noireau F, Carrasco HJ, Miles MA. Chagas disease in the Amazon Basin: association of Panstrongylus geniculatus (Hemiptera: Reduviidae) with domestic pigs. J Med Entomol. 1998;35:99-103.

24. Valente VC. Potential for domestication of Panstrongylus geniculatus (Latreille, 1811) (Liemiptera, Reduviidae, Triatominae) in the Municipality of Muaná, Marajó Island, State of Pará, Brazil. Mem Inst Oswaldo Cruz. 1999;94 Suppl 1:399-400.

25. Miles MA, Souza AA, Póvoa M. Chagas' disease in the Amazon Basin III. Ecotopes of ten triatomine bug species (Hemiptera, 
Reduviidae) from the vicinity of Belém, Pará State, Brazil. J Med Entomol. 1981;18:266-78.

26. Zeledon R. Vectores de la enfermedad de Chagas y sus características ecofisiológicas. Interciencia. 1983;8:384-95.

27. Serrano O, Mendoza F, Suárez B, Soto A. Seroepidemiología de la enfermedad de Chagas en dos localidades del municipio Costa de Oro, estado Aragua, Venezuela. Biomedica. 2008;28:108-15.

28. Reyes-Lugo M, Rodriguez-Acosta A. Domiciliation of the sylvatic Chagas disease vector Panstrongylus geniculatus (Triatominae: Reduviidae) in Venezuela. Trans R Soc Trop Med Hyg. 2000;94:508.

29. Angulo VM, Esteban L, Luna KP. Eficacia en campo de un repelente a base de para-mentano-3,8-diol y aceite de limonaria contra Culicoides pachymerus (Diptera: Ceratopogonidae) en Colombia. Biomedica. 2012;32:277-85.

30. Naiff MF, Naiff RD, Barett TV. Vetores selváticos de doença de Chagas na área urbana de Manaus (AM): atividade de vôo nas estações secas e chuvosas. Rev Soc Bras Med Trop. 1998;31:103-5.

31. Fé NF, Magalhães LK, Fé FA, Arakian SK, Monteiro WM, Barbosa MG. Ocorrência de triatomíneos em ambientes silvestres e domiciliares do município de Manaus, Estado do Amazonas. Rev Soc Bras Med Trop. 2009;42:642-6.

32. Maeda MH, Knox MB, Gurgel-Gonçalves R. Occurrence of synanthropic triatomines (Hemiptera: Reduviidae) in the Federal District of Brazil. Rev Soc Bras Med Trop. 2012;45:71-6.

33. Cáceres AG, Troyes L, Gonzáles-Pérez A, Llontop E, Bonilla C, Murias E, et al. Enfermedad de Chagas en la región nororiental del Perú. I. Triatominos (Hemiptera, Reduviidae) presentes en Cajamarca y Amazonas. Rev Peru Med Exp Salud Publica. 2002;19:17-23.

34. Torres V DB, Cabrera R. Geographical distribution and intradomiciliary capture of sylvatic triatomines in La Convención province, Cusco, Peru. Rev Inst Med Trop São Paulo. 2010;52:157-60

35. Depickère S, Durán P, López R, Chávez T. Presence of intradomicile colonies of the triatomine bug Panstrongylus rufotuberculatus in Muñecas, La Paz, Bolivia. Acta Trop. 2011;117:97-100.
36. Depickère S, Duran P, Lopez R, Martinez E, Chavez T. After five years of chemical control: colonies of the triatomine Eratyrus mucronatus are still present in Bolivia. Acta Trop. 2012;123:234-8.

37. Damborsky MP, Bar ME, Oscherov EB. Detección de triatominos (Hemiptera: Reduviidae) en ambientes domésticos y extradomésticos, Corrientes, Argentina. Cad Saude Publica. 2001;17:843-9.

38. Wolff M, Castillo D. Evidencias de domesticación y aspectos biológicos de Panstrongylus geniculatus (Latreille, 1811) (Hemiptera: Reduviidae). Acta Entomol Chil. 2000;24:77-83.

39. Noya-Alarcón O, Botto C, Cortez J, Ferrer E, Viettri M, Herrera L. Primer registro de Panstrongylus geniculatus (Latreille, 1811) en los municipios Alto Orinoco y Atures, estado Amazonas, Venezuela. Bol Malariol Salud Ambient. 2011;51:81-5.

40. Soto H, Tibaduiza T, Montilla M, Triana O, Suárez DC, Torres MT, et al. Investigación de vectores y reservorios en brote de Chagas agudo por posible transmisión oral en Aguachica, Cesar, Colombia. Cad Saude Publica 2014;30:746-56.

41. Noireau F, Abad-Franch F, Valente AS, Dias-Lima A, Lopes CM, Cunha V, et al. Trapping Triatominae in silvatic habitats. Mem Inst Oswaldo Cruz. 2002;97:61-3.

42. Obara MT, Ceretti Junior W, Urbinatti PR, Papa AR, Quintero LO, Barata JM. Sistema de armadilha modificada para captura de Triatomíneos (Hemiptera: Reduviidae) em diferentes ecótopos. Entomol Vect. 2002;9:583-90.

43. Alarcón de Noya B, Díaz-Bello Z, Colmenares C, Ruiz-Guevara R, Mauriello L, Zavala-Jaspe R, et al. Large urban outbreak of orally acquired acute Chagas disease at a school in Caracas, Venezuela. J Infec Dis. 2010;201:1308-15.

44. Rodrigues VL, Silva RA, Wanderley DM, Carvalho ME, Pauliquevis Junior CP. Detecção de triatomíneos da espécie Rhodnius neglectus em área urbana de municípios da região de Araçatuba. Bol Epidemiol Paulista. 2009;6:20-3.

45. Dias JV, Queiroz DR, Martins HR, Gorla DE, Pires HH, Diotaiuti L. Spatial distribution of triatomines in domiciles of an urban area of the Brazilian Southeast Region. Mem Inst Oswaldo Cruz. 2016;111:43-50.

46. Dias JP, Bastos C, Araújo E, Mascarenhas AV, Martins Netto E, Grassi F, et al. Acute Chagas disease outbreak associated with oral transmission. Rev Soc Bras Med Trop. 2008;41:296-300. 